\title{
AGEING AND PRODUCTION OF THE CYTOKINES IN CHERNOBYL CLEAN-UP WORKERS FROM LATVIA
}

\author{
Natalja Kurjāne*, Rūta Brūvere**, Natālija Gabruševa**, Elvīra Hagina*, Tija Zvagule*, \\ Inta Jaunalksne*, Guna Feldmane ${ }^{* * *}$, Ârija Volrāte, and Natālija Voskresenska* \\ * Stradiṇš Clinical University Hospital, Pilsoṇu iela 13, Rīga, LV-1002, LATVIA, \\ e-mail: natalja.kurjane@ @otmail.com \\ ** Biomedical Research and Study Centre, University of Latvia, Rātsupītes iela 1, Rīga, LV-1067, LATVIA \\ ${ }^{* * *}$ Augusts Kirhenšteins Institute of Microbiology and Virology, Rātsupītes iela 1, Rīga, LV-1067, LATVIA
}

Communicated by Aina Muceniece

\begin{abstract}
Chronic low-grade inflammation with subsequent impairment of immune system function promotes the development of age-related diseases, such as cancers, degenerative and infection diseases. It is not yet clear, if exposure to ionising radiation accelerates the aging process. The aim of the present work was to estimate the production of several cytokines by peripheral blood cells of Latvia's Chernobyl clean-up workers depending on age. ELISA was employed to determine the plasma level of sIL-1 $\beta$ and sIL-6 as well as level of IL-4 and TNF- $\alpha$ spontaneous and $24 \mathrm{~h}$ and $96 \mathrm{~h}$ after in vitro stimulation of peripheral blood mononuclear cell cultures by lipopolysaccharide (LPS) and phytohemagglutinin (PHA) mitogens were determined in 40 Chernobyl clean-up workers 17 years after their work in Chernobyl and in 42 blood-donors without a history of occupational radiation exposure. The ability of peripheral blood leukocytes (PBL) to produce interferons (IFNs) was determined in 73 Chernobyl clean-up workers 15 years after the work in Chernobyl and in age-matched 63 blood-donors. IFNs were tested in whole blood cultures by standard virus cytopathic inhibition micromethod after their in vitro induction by Newcastle disease virus, phytohemagglutinin or double-stranded RNA. Individuals were divided into three age groups: age $<40$, age 40-49 and age $>50$. The ability of PBL to produce IFN was significantly decreased in all Chernobyl clean-up worker age groups in comparison with blood-donors (control groups). The incidence of good ability to produce IFN gradually decreased with age in the control group, but increased with age in aged-matched Chernobyl clean-up workers groups. The production TNF- $\alpha$ and IL-4 by peripheral blood mononuclear cells as well as sIL-1 $\beta$ level in plasma showed no significant differences between all the examined age groups. The slL-6 level was gradually increased with age in Chernobyl clean-up workers. Our results showed that the concentration of pro-inflammation cytokine sIL-6 in peripheral blood plasma, as well as the ability of PBL to produce IFNs, in Chernobyl clean-up workers from Latvia is age dependent.
\end{abstract}

Key words: ageing, Chernobyl accident, IL-4, sIL-6, sIL-1 $\beta$, TNF- $\alpha$, IFNs, cell immunity.

\section{INTRODUCTION}

It is still not clear if exposure to ionizing radiation accelerates the ageing process (Sasaki et al., 1991; Chumak et al., 2001). Information about changes in different parts of the immune system by ageing are contradictory (De Paoli et al., 1988; Rea et al., 1996; Bruunsgard et al., 2000; Yen et al., 2000; Nerlan et al., 2002; Schindovski et al., 2002). Recent investigations confirm ageing to be associated with increased inflammatory activity reflected by increased levels of circulating proinflammatory cytokines (Franceschi et al., 2000; Franceschi and Bonafe, 2003). Chronic low-grade inflammation with subsequent impairment of immune system function during aging promotes the development of agerelated diseases, such as cancers, degenerative and infection diseases. In the same way, increased inflammatory activities have been observed after radiation exposure (Qurmby et al., 1999; Van Der Meeren et al., 1999).

Approximately 6,000 men in Latvia were affected by ionising radiation during work in Chernobyl to clean up the after-effects of the Chernobyl power plant accident. Morbidity of workers increased progressively year by year significantly exceeding that of the overall population (Brūvere et al., 2002).

The aim of the present work was to determine the production of several cytokines by peripheral blood cells of Chernobyl clean-up workers depending on age. 


\section{MATERIALS AND METHODS}

A total of 113 Chernobyl clean-up workers (who participated during 1986 in the clean-up work), 15-17 years after the work in Chernobyl, and 105 blood-donors (Latvia's men) without a history of occupational radiation exposure were examined in this study.

The ability of peripheral blood leukocytes (PBL) to produce IFNs was determined in 73 Chernobyl clean-up workers and in 63 age-matched blood-donors. Other cytokines (sIL-1 $\beta$, sIL-6, IL-4, TNF- $\alpha$ ) as well as lymphocytes subpopulations were determined in 40 Chernobyl clean-up workers 17 years after they worked in Chernobyl and in 42 blood donors. Individuals were divided in three age groups: age $<40$, age 40-49 and age $>50$.

Plasma concentrations of soluble IL-1 $\beta$ and IL- 6 cytokines were measured by ELISA (R\&D systems, Minneapolis, USA). Level IL-4 and TNF-i spontaneous and after stimulation by lipopolysaccharide (LPS) and phytohemagglutinin (PHA) mitogens after $24 \mathrm{~h}$ and $96 \mathrm{~h}$ in peripheral blood mononuclear cell (PBMC) culture supernatants were measured by ELISA (Biosource International, Belgium). IFNs were tested in whole blood cultures by the standard virus cytopathic inhibition micromethod after their in vitro induction by Newcastle disease virus, phytohemagglutinin or double-stranded RNA. The number of PBL, monocytes, lymphocytes and their subpopulations $(\mathrm{CD} 3+, \mathrm{CD} 4+$, CD8+, CD16+, CD19+, CD25+) were determined by flow cytometry using the appropriate specific monoclonal antibodies Becton Dickenson, USA in the peripheral blood.

The levels of immunoglobulins (IgA, $\operatorname{IgG}$ and $\operatorname{IgM}$ ) were detected by nephelometry in the blood serum.

Statistical analysis. Data were statistically analysed using the ANOVA test. The level of significance was set at $P<$ 0.05 .

\section{RESULTS}

The incidence of good ability of PBL to produce IFNs (100-400 IU) was significantly decreased in Chernobyl clean-up workers in comparison with blood-donors (control group) (Fig. 1a,1b,1c). An exception was the 2 years age Chernobyl clean-up worker group) (Figure 1c). In this group the incidence of good ability to produce IFN after induction by PHA was significantly higher than that in the age-matched blood donors. The incidence of good ability of PBL to produce IFNs induced by PHA significantly increased with age in Chernobyl clean-up workers, while the incidence of good ability to produce IFN gradually decreased with age (by each of the three inducers) in the control group.

The incidence of inability to produce IFN in the youngest Chernobyl clean-up worker group $(<40)$ was significantly greater in comparison with the age-matched control group (Fig. 2a). At age 40-49 years, the difference between
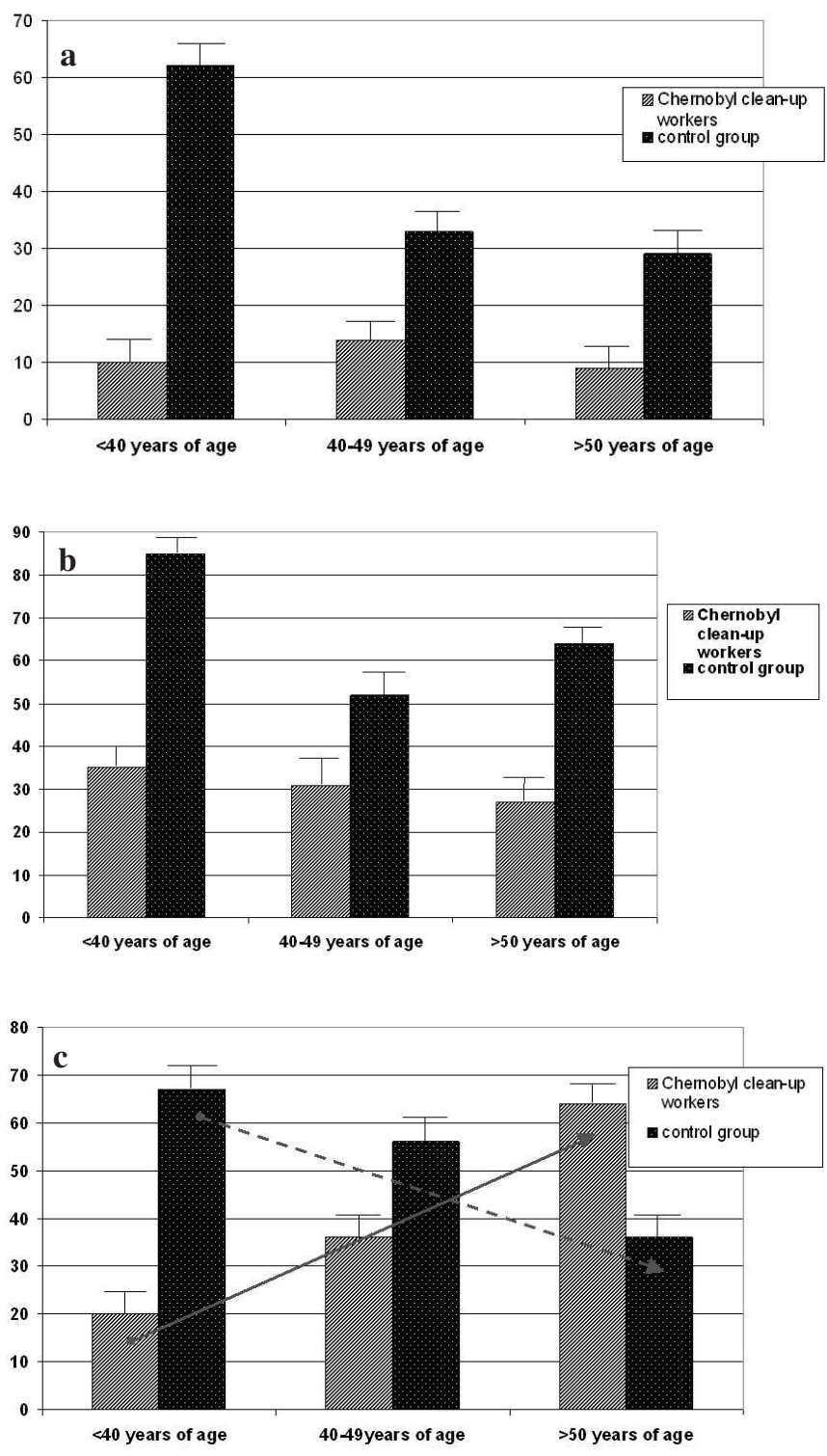

Fig. 1. a) Incidence of good ability (\%) of PBL to produce interferons (100-400 IU) to NDV depending on age; b) incidence of good ability (\%) of PBL to produce interferons (100-400 IU) to dsRNS depending on age; c) incidence of good ability $(\%)$ of PBL to produce interferons (100-400 IU) to PHA depending on age $(P<0.01)$

clean-up workers and blood donors was not significant (Fig. $2 b)$. More blood-donors were unable to produce IFN after induction by dsRNA in comparison with Chernobyl cleanup workers in age groups over 50 (Fig. 2c).

The production of IL-4 as well as TNF- $\alpha$, spontaneously as well as after stimulation by PHA or LPS in Chernobyl clean-up workers blood cells was very low and similar in all age groups. The production of TNF- $\alpha$ by LPS and PHA after 96 hours in PBMC, in Chernobyl clean-up workers was lower in comparison with blood donors, but not significantly.

The concentration of soluble IL-6 was significantly higher in the Chernobyl clean-up workers after 40 years of age, but the level of soluble IL-1 $\boldsymbol{\beta}$ did not differ between groups. 

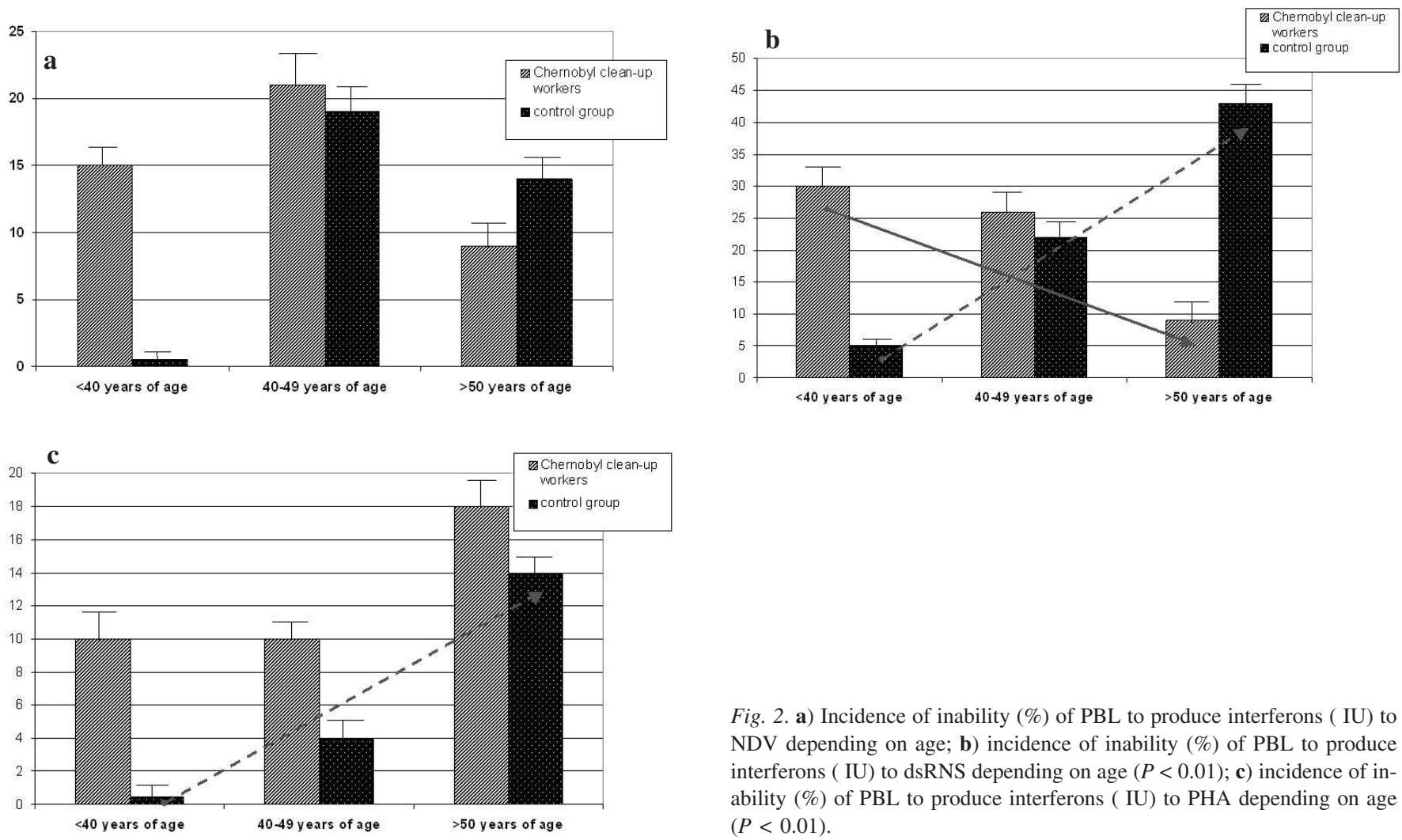

Fig. 2. a) Incidence of inability (\%) of PBL to produce interferons ( IU) to NDV depending on age; $\mathbf{b})$ incidence of inability (\%) of PBL to produce interferons ( IU) to dsRNS depending on age $(P<0.01)$; $\mathbf{c})$ incidence of inability $(\%)$ of PBL to produce interferons ( IU) to PHA depending on age $(P<0.01)$.

Table 1

IMMUNOLOGICAL PROFILE OF CHERNOBYL CLEAN-UP WORKERS AND DONORS DEPENDING ON AGE

\begin{tabular}{|c|c|c|c|c|c|c|}
\hline \multirow[t]{2}{*}{ Indices } & \multicolumn{2}{|c|}{ Age $<40$} & \multicolumn{2}{|c|}{ Age 41-49 } & \multicolumn{2}{|c|}{ Age $>50$} \\
\hline & clean-up workers & donors & clean-up workers & donors & clean-up workers & donors \\
\hline PBL & $7,040 \pm 2,428$ & $6,058 \pm 1,004$ & $8,241 \pm 2,058^{*}$ & $5,269 \pm 1,402 *$ & $7,562 \pm 1,547$ & $6,371 \pm 1,447$ \\
\hline Ly, \% & $30.4 \pm 4.8^{*}$ & $37 \pm 5.8^{*}$ & $26.7 \pm 6.0$ & $34.4 \pm 7.2$ & $31.3 \pm 7.8$ & $32.7 \pm 6.6$ \\
\hline Mo, \% & $5.2 \pm 1.9$ & $4.6 \pm 1.6$ & $7.1 \pm 2.4$ & $4.7 \pm 2.2$ & $6.7 \pm 2.1$ & $5.6 \pm 2.1$ \\
\hline $\mathrm{CD} 3+, \%$ & $60.8 \pm 9.3 *$ & $73.5 \pm 7.8^{*}$ & $70.8 \pm 8.3$ & $70.9 \pm 9.4$ & $72.8 \pm 13.4$ & $69.1 \pm 11.9$ \\
\hline $\mathrm{CD} 4+, \%$ & $37.8 \pm 6.7$ & $42.6 \pm 7.3$ & $45.1 \pm 7.6^{*}$ & $39.3 \pm 7.0^{*}$ & $39.2 \pm 9.6$ & $39.0 \pm 6.6$ \\
\hline $\mathrm{CD} 8+, \%$ & $25.0 \pm 11.5$ & $30.4 \pm 7.2$ & $25.4 \pm 6.5^{*}$ & $33.5 \pm 10.7 *$ & $37.2 \pm 13.3$ & $30.1 \pm 14.2$ \\
\hline $\mathrm{CD} 16+, \%$ & $28.4 \pm 10.9^{*}$ & $15.0 \pm 7.1 *$ & $15.6 \pm 7.4$ & $16.0 \pm 5.9$ & $15.9 \pm 9.7$ & $18.3 \pm 10.2$ \\
\hline CD19+, \% & $11.6 \pm 1.3$ & $11.4 \pm 4.2$ & $11.8 \pm 6.1$ & $9.7 \pm 4.4$ & $9.0 \pm 4.1$ & $12.4 \pm 10.0$ \\
\hline $\mathrm{CD} 25+, \%$ & $5.8 \pm 1.4 *$ & $3.1 \pm 1.2 *$ & $3.7 \pm 1.6$ & $3.4 \pm 1.7$ & $3.7 \pm 1.1$ & $3.0 \pm 1.0$ \\
\hline $\operatorname{Ig} \mathrm{A}, \mathrm{mg} \%$ & $2.1 \pm 0.6$ & $2.5 \pm 0.7$ & $2.2 \pm 0.8$ & $2.2 \pm 0.8$ & $2.9 \pm 0.9$ & $2.3 \pm 0.8$ \\
\hline $\mathrm{IgG}, \mathrm{mg} \%$ & $12.1 \pm 2.1$ & $10.9 \pm 2.1$ & $11.1 \pm 3.3$ & $10.4 \pm 1.8$ & $11.5 \pm 2.7$ & $11.7 \pm 2.5$ \\
\hline $\operatorname{IgM}, \mathrm{mg} \%$ & $1.6 \pm 0.4$ & $1.1 \pm 0.6$ & $1.1 \pm 0.4$ & $1.2 \pm 0.6$ & $1.2 \pm 0.4$ & $0.9 \pm 0.6$ \\
\hline sIL-6, pg/ml & $\begin{array}{c}6.4 \pm 1.2 * * \\
\mathrm{n}=21\end{array}$ & $\begin{array}{c}3.7 \pm 0.9^{* *} \\
\mathrm{n}=20\end{array}$ & $\begin{array}{c}9.2 \pm 0.7 * / * * \\
\mathrm{n}=19\end{array}$ & $\begin{array}{c}4.2 \pm 0.9^{*} \\
\mathrm{n}=22\end{array}$ & n.d. & n.d. \\
\hline $\mathrm{sIL}-1 \beta, \mathrm{pg} / \mathrm{ml}$ & $\begin{array}{c}7.8 \pm 0.6 \\
\mathrm{n}=21\end{array}$ & $\begin{array}{c}7.1 \pm 1.2 \\
\mathrm{n}=20\end{array}$ & $\begin{array}{c}6.7 \pm 0.3 \\
\mathrm{n}=19\end{array}$ & $\begin{array}{c}6.9 \pm 0.9 \\
n=22\end{array}$ & n.d. & n.d. \\
\hline
\end{tabular}

PBL, peripheral blood leukocytes; IgA, IgG, IgM, immunoglobulins; $* P<0.05$, Chernobyl clean-up workers versus donors between age-matched groups; $* * P<0.05$, Chernobyl clean-up workers versus donors and clean-up workers between different age groups; n.d. - no data

Comparison of cell-immunity parameters in Chernobyl clean-up workers and control groups showed some significant differences (Table 1):

- Age < 40: Chernobyl clean-up workers had a significantly lower percentage of lymphocytes, but increased number of CD16+ and CD25+ cells in comparison with age-matched donors;

- Age 40-49: Chernobyl clean-up workers had significantly higher number of PBL, monocytes, CD4+cells and decreased number of CD8+ cells in comparison with the control group; 
- Age > 50: Chernobyl clean-up workers had an increased number of $\mathrm{CD} 8+$ cells compared with donors.

\section{DISCUSSION}

Ageing is associated with changes in most parts of the immune system (Rea et al., 1996; Franceschi et al., 2000; Mysliwska et al., 2000; Yen et al., 2000; Weksler et al., 2002; Schindovski et al., 2002). A causal ration between impaired immune function during ageing and increased susceptibility to infections and cancers remains to be demonstrated. Ageing is associated with chronic low-grade inflammatory activity (Franceschi et al., 2000; Franceschi and Bonafe, 2003). As has been shown in several studies that the level of TNF $\alpha$, IL-6, IL-1Ra increases with age (Bruunsgaard et al., 2001). Immunosenescence is characterised by impaired cellular immunity combined with low-grade inflammation. Possible, chronic low-grade inflammatory activity may cause exhaustion of $\mathrm{T}$ lymphocytes through long-term activation and bystander proliferation.

An important part of human ageing is a decline in the ability of individuals to adapt to environmental stress. The hypothesis that exposure to ionising radiation accelerates the natural processes of ageing has been investigated in a population of A-bomb survivors in Japan by means of clinical, epidemiological, and laboratory methods (Sasaki et al., 1991). Immunological changes among A-bomb survivors in PHA response and mixed lymphocyte culture response showed equivocal radiation effects. The frequency of $\mathrm{T}$ lymphocyte TCR mutation increased with age and also with radiation dose (Sasaki et al., 1991). Chumak et al. (2001) suggested that early ageing of the immune system was a result of radiation exposure. The immunological reactions of the heavily irradiated Chernobyl accident victims and clean-up workers differed during the period of the acute radiation syndrome and during the recovery period. In the recovery period inhibition of immune function remained; this was associated with changes in lymphocyte subsets, such as decreased CD3+ and CD4+ T-lymphocyte counts and increased numbers of somatic mutations at the T-cell receptor locus (Chumak et al., 2001).

$\mathrm{T}$ cells, which are central to the correct functioning of the immune system, decline with age due to thymus involution (Aspinall and Andrewe, 2000). A significantly decreased number of total T lymphocytes in CD3 and in the CD4 and CD8 subsets was observed in aged humans by Schindovski et al. (2002). A lack of T cells may be one of the numerous causes of immunosenescence, since fewer cells providing immune function are available to maintain immune homeostasis. Age-related impaired $\mathrm{T}$ cell function is associated with increased mortality risk.

In our study, we did not observe any significant age-related changes in cell subsets in control groups, which supports some previous studies (Yen et al., 2000). In Chernobyl clean-up workers the number of CD8+ cells increased, but the number of CD25+ cells gradually decreased with age. Possibly, the lack of differences in T-cell subsets between the investigated age-related groups in the control group in the current study could be explained by the chosen groups for investigation, i.e. the age differences were not large enough. Nerlan et al. (2002) as well as Franceschi et al. (2000) reported an increase of IL-6 and TNF- $\alpha$ production by $\mathrm{T}$ cells in peripheral blood in elderly subjects that could be due to basal inflammation by age. TNF- $\alpha$, a proinflammatory cytokine, has a central role in the stimulation of cellular and inflammatory reactions. Fagiolo and TorianiTerenzi (2002) observed high TNF- $\alpha$ levels both in lipopolysaccharide stimulated and unstimulated blood mononuclear cells after irradiation. Our obtained data did not show any change in TNF- $\alpha$ production in Chernobyl clean-up workers. Regarding IFNs, previous experimental investigations of IFN- $\gamma$ production show opposite effects depending on age and/or irradiation: increased as well as decreased level of interferon (Ганова $u$ дp., 1994; Алимбарова $и$ дp., 1997; Zhang et al., 2000; Zhang et al., 2002; Griffin et al., 2006). The evaluation of the interferon status of children living in areas with increased radiation background revealed a reduced capacity of blood lymphocytes to produce gamma-interferon as well as an increased level of circulating interferon in serum (Алимбарова $и д p$., 1997). The results of our study showed a decreased IFNs common production in the liquidators from Latvia 15 years after the Chernobyl disaster. However, the incidence of good ability of peripheral blood leukocytes to produce IFNs induced by PHA mitogen significantly increased with age in Chernobyl clean-up workers.

Natural killer lymphocytes are considered to be involved in immunosurveillance against tumours and in viral defence. Their age-related changes in activity are still controversially discussed in the literature (Mysliwska et al., 2000; Schindovski et al., 2002), but most studies show increased number and activity of NK cells with advancing age. In contrast, irradiation has an inhibitory effect on human NK activity (Fuggetta et al., 1998). In our study a significant correlation with age in the percentage of NK cells was found in Chernobyl clean-up workers - the number of NK cells gradually decreased whereas in the control group we did not observe any changes with age.

On the other hand, Burns et al. (1993) reported that a decline of immune function with age is due to impaired $\mathrm{B}$ cells function but is not restricted to T lymphocytes (Burns et al., 1993). However, defective $\mathrm{T}$ helper activity might contribute to an altered B cell functionality and could account for one aspect of the altered humoral activity associated with age (Burns et al., 1997). The age-associated decrease in the antibody response to foreign antigens suggests that immune senescence leads to the most common immunodeficiency state or disregulation (Weksler et al., 2002). The number of blood B cells secreting immunoglobulins was observed to increase with age but the serum concentration of the immunoglobulins did not decrease with age (Weksler et al., 2002). Possibly, the basis for age-associated 
polyclonal B cell activation depends on the increased production of IL-4 and IL-6 production by T cells in the elderly. In our study we did not observe any changes in immunoglobulin production in Chernobyl clean-up workers or in control groups.

In conclusion, we found that the concentration of proinflammation cytokine sIL-6 in peripheral blood as well as the ability of PBL to produce IFNs after PHA stimulation in $24 \mathrm{~h}$ in Chernobyl clean-up workers from Latvia were correlated with age. We suggest that ongoing ageing processes are reflected by the induction of IFNs of leukocytes in both examined groups: in Chernobyl clean-up workers as well as in donors. However, the character of the production differs: increases in clean-up workers with age, but decreases in donors. The increased plasma levels of soluble IL-6 might be the consequence of an age-dependent inflammatory reaction in Chernobyl clean-up workers as well as of the presented incorporated radionuclides.

\section{REFERENCES}

Aspinall, R., Andrewe, D. (2000). Thymic involution in aging. J. Clin. Immun., 20(4), 250-256.

Bruunsgaard, H., Pedersen, M., Pedersen, B.K. (2001). Aging and inflammatory cytokines. Curr. Opin. Hemat., 8, 131-136.

Bruunsgaard, H., Pedersen, A., Schroll, M., Skinnoj, P., Pedersen, B. (2000). Proliferative responses of blood mononuclear cells (BMNC) in a cohort of elderly humans: Role of lymphocyte phenotype and cytokine production. Clin. Exp. Immunol., 119, 433-440.

Brūvere, R., Volrāte, A., Gabruševa, N., Heisele, O., Feldmane, G., Balodis, V. (2002). Functional deficiency of the immune system of Chernobyl accident clean-up workers residing in Latvia. Proc. Latvian Acad. Sci., Section B, 57(1/2), 17-21.

Burns, E., Lum, L., L'Hommedieu, G., Goodvin, J. (1993). Specific humoral immunity in the elderly: in vivo and in vitro response to vaccination. $J$. Gerontol., 48, B231-B236.

Chumak, A., Thevenon, Ch., Gulay, N., Guichardant, M., Margitich, V., Bazyka, D., Kovalenko, A., Lagarde, M., Prigent, A. (2001). Monohydroxylated fatty acid content in peripheral blood mononuclear cells and immune status of people at long times after the Chernobyl accident. Radiat. Res., 156, 476-487.

De Paoli, P., Battistin, S., Santini, G. (1988). Age-related changes in human lymphocyte subsets: Progressive reduction of the CD4CD45R population. Clin. Immunol. Immunopathol., 48, 290-296.

Fagiolo, E. and Toriani-Terenzi, C. (2002). IFN-gamma and TNF-alpha production in gamma-irradiated blood units by mononuclear cells and GVHD prevention. Transfus. Apher. Sci., 27(3), 225-231.

Franceschi, C., Bonafe, M., Valensin, S., Olivieri, F., De Luca, M., Ottaviani, E., De Benedictis, E. (2000). Inflamm-aging. An evolutionary perspective on immunosenescence. Annals. N. Y. Acad. Sci., 908, 244-254.

Franceschi, C., Bonafe, M. (2003). Centenarians as a model for healthy aging. Bioch. Soc. Trans., 31(2), 457-461
Fuggetta, M., Tricarico, M., Starace, G., Pepponi, R., Bonmasser, E. (1998). Interferons antagonize ć-Ray-induced depression of natural immunity. $J$. Radiat. Oncol. Biol. Phys., 40(1), 953-960.

Griffin, R., Nally, R., Nolan, Y., McCarthey, Y., Linden, J., Lynch, M. (2006). The age-related attenuation in long-term potentiation is associated with microglial activation. J. Neurochem., 99(4), 1263.

Mysliwska, Y., Bryl, E., Trzonkowski, P., Mysliwski, A. (2000). Compensatory effect of TNFi on low natural killer activity in the elderly. Acta Bioch. Polon., 47(2), 301-311.

Nerlan, S., Rea, I., Alexander, H. (2002). A whole blood for measurement of intracellular TNF- $\alpha$, IFN- $\gamma$ and IL-2 expression in stimulated CD3+ lymphocytes: Differences between young and elderly subjects. Experim. Gerontol., 37, 227-234.

Quarmby, S., Kumar, P., Kumar, S. (1999). Radiation-induced normal tissue injury: Role of adhesion molecules in leukocyte-endothelial cell interactions. Int. J. Canc., 82(3), 385-395.

Rea, I., Stewart, M., Campbell, P., Alexander, H., Crockard, A., Morris, T. (1996). Changes in lymphocyte subsets, IL-2, and IL-2 receptor in old and very old age. Gerontol., 42, 69-78.

Sasaki, H., Kodami, K., Yamada, M. (1991). Aging. J. Radiat. Res. Suppl., 310-326.

Schindovski, K., Frohlich, L., Maurer, K., Muller, W., Eckert, A. (2002). Age-related impairment of human T lymphocytes' activation: Specific differences between CD4+ and CD8+ subsets. Mech. Age. Develop., 123, 375-390.

Van Der Meeren, A., Squiban, C., Gourmelon, P., Lafont, H., Gaugler, M. (1999). Differential regulation by IL-4 and IL-10 of radiation-induced IL-6 and IL-8 production and ICAM-1 expression by human endothelial cells. Cytokine, 11(11), 831-838.

Weksler, M., Goodhardt, M., Szabo, P. (2002). The effect of age on B cell development and humoral immunity. Springer Semin. Immunopathol., 24, $35-52$.

Yen, Ch., Lin, Sh., Huang, K., Lin, R. (2000). Age-associated changes in interferon-ć and interleukin- 4 secretion by purified human CD4+ and CD8+ T cells. J. Biomed. Sci., 7, 317-321.

Zhang, Y., Acuna, C., Switzer, K., Song, L., Sayers, R., Mbawuike, I. (2000). Corrective effects of Interleukin-12 on age-related deficiencies in IFN-gamma production and IL-12Rbeta2 expression in virus-specific CD8+ T cells. J. Interf. Cyt. Res., 20(2), 235-245.

Zhang, X., Fujii, H., Kishimoto, H., LeRoy, E., Surh, C., Sprent, J. (2002). Aging leads to disturbed homeostasis of memory phenotype CD8(+) cells. J. Exp. Med., 195(3), 283-293.

Zhang, H.G., Grizzle, W.E. (2003). Aging, immunity, and tumor susceptibility. Immunol. Allerg. Clin. North Amer., 23(1), 83-102.

Алимбарова А., Соха, Л., Балева Л., Лаврухина Л., Баринский И. (1997). Оценка иммунитета и интерферонового статуса детей, инфицированных вирусом Herpes simplex, и проживающих на территории с повышенной радиоактивностью [Evaluation of the immune and interferon status of children infected with Herpes simplex virus and living in areas with increased radiation background]. Вопрось Вирусологии, 42(1), 36-41.

Ганова Л., Сливак Н., Олевинская 3. (1994). Нарушения иммунного ответа у мышей под длительным воздействием радиации и возможности их коррекции альфа-интерфероном [Disorders of immunologic response in mice under prolonged radiation effects and possibilities of their correction with alpha-interferon]. Радиаи. биология, Радиоэкология, 34(3), 402-406. 


\section{NOVECOŠANĀS UN CITOKĪNU SINTĒZE ČERNOBIḶAS AVĀRIJAS SEKU LIKVIDĒTĀJIEM NO LATVIJAS}

Šobrīd pasaulē vērojama padziḷināta interese par priekšlaicīgas novecošanās patoǵenēzi. Mūsdienu vienotās novecošanas teorija atzīst, ka visraksturīgākais novecošanās procesam ir progresīvi pieaugošs proiekaisuma stāvoklis, kas pavada adaptācijas mazspēju. Vispārzināms ir fakts, ka jonizējošā radiācija paātrina audu novecošanos. Radiācijas izraisītā audu bojājuma sekas ir iekaisums, kurā iesaistās citokīni signālpolipeptīdi, ko izstrādā galvenokārt imūnās sistēmas aktivētas šūnas. Radiācijas izraisītā iekaisumā, kas var būt gan akūts, gan hronisks, piedalās pro-iekaisuma citokīni: IL-6, IL-1 $\alpha$, IL-1 $\beta$, TNF- $\alpha$ un citi. Nepārtrauktā iekaisuma stimulu klātbūtne veido bioloğisko pamatu paaugstinātai predispozīcijai attiecībā pret t.s. vecuma slimībām un paaugstina risku saslimt ar ḷaundabīgiem audzējiem. Černobiḷas avārijas seku likvidētāji, kuri savulaik bija pakḷauti relatīvi īslaicīgam ārējām apstarojumam un visu atlikušo dzīvi ir inkorporēto radionuklīdu „nēsātāji”, no zinātniskās izpētes viedokḷa ir interesanta grupa, tai skaitā attiecībā uz novecošanās procesa dinamiku saistībā ar proiekaisuma citokīnu līmeṇa pārmain̄ām. Sakarā ar to, ka ik gadus pasaules vispārējais radiācijas fons pieaug, jautājums pārsniedz vien tikai „Černobiḷas” ietvarus. Mūsu darba mērķis bija novērtēt dažu citokīnu (interferonu, IL-1 $\beta$, IL-4, IL-6, TNF- $\alpha$ ) sintēzi Černobiḷas avārijas seku likvidētājiem atkarībā no vecuma salīdzinājumā ar atbilstoša vecuma vīriešiem, kuriem nav bijusi profesionāla saskarsme ar jonizējošo radiāciju (kontroles grupu). Pētījums veikts Arodslimību un staru patolog̣ijas centrā VAS Paula Stradina KUS 2001.-2003. gadā. Kopumā izmeklēti 113 Černobiḷas avārijas seku likvidētāji, kas 1986. gada maijā piedalījušies avārijas seku likvidācijas darbos un 103 atbilstoša vecuma un dzimuma Latvijas iedzīvotāji, kas netika pakḷauti radiācijas darbībai (kontroles grupa). Personas tika sadalītas trijās dažāda vecuma grupās: (< 40 gadi; 40-49 gadi; > 50 gadi). sIL-1 $\beta$ un sIL-6 citokīnu līmenis tika noteikts asins plazmā 42 likvidētājiem un 40 donoriem. Citokīnu IL-2, IL-4 un TNF- $\alpha$ spontāna indukcija un ar mitogēniem fitohemaglutinīnu (PHA) un lipopolisaharīdu (LPS) stimulēta ierosa izmeklējamo personu perifēro asiṇu mononukleāro šūnu kultūrās tika vērtēta pēc 24 un 96 stundām. Perifēro asiṇu leikocītu spēja ražot interferonus pēc to in vitro indukcijas ar trim dažādiem induktoriem: fitohemaglutinīnu, N̦ūkāstlas slimības vīrusu un divpavedienu RNS tika pētīta 73 Černobiḷas avārijas seku likvidētājiem un 63 donoriem. Rezultātus noteicām, titrējot ar vīrusu citopātiskās inhibīcijas standarta metodi pārprotējamo audu kultūrā L-41, kā testa vīrusu izmantojot encefalomiokardīta vīrusu. Interferonu sintēze visiem Černobiḷas avārijas seku likvidētājiem bija samazināta, salīdzinot ar kontroles grupu. Tomēr likvidētāju grupā fitohemaglutinīna-inducēta interferonu veidošanās (pēc 24 st.) palielinās tieši proporcionāli vecumam, bet kontoles grupā - otrādi, samazinās. sIL-6 koncentrācija bija statistiski ticami augstāka likvidētāju grupā pēc 40 gadiem. TNF- $\alpha$ un IL-4 indukcija neatšķiras starp Černobiḷas avārijas seku likvidētājiem un donoriem. Iegūtie dati var liecināt par interferonu sistēmas piedalī̌sanos ar vecumu nosacīta iekaisuma procesā: Černobilas avārijas seku likvidētājiem ar vecumu pieaug, bet donoriem - samazinās. Paaugstināta sIL-6 pro-iekaisuma citokīna koncentrācija perifērajās asinīs Černobiḷas avārijas seku likvidētājiem var norādīt uz iekaisuma procesu organismā inkorporēto radionuklīdu esamības vai arī dabīgas novecošanas dēḷ. 